\title{
PENGARUH KEBIASAAN BELAJAR TERHADAP MOTIVASI BELAJAR SISWA
}

\section{STUDY HABITS INFLUENCE MOTIVATION TOWARDS LEARNING STUDENTS}

\author{
S Hasanah'1a, O Abdurakhman'1, dan M Ichsan'1 \\ ${ }^{1}$ Program Studi Pendidikan Guru Sekolah Dasar, Fakultas Keguruan dan Ilmu Pendidikan, Universitas \\ Djuanda Bogor, Jl. Tol Ciawi No. 1 Kotak Pos 35 Ciawi Bogor 16720 \\ a Korespondensi: Siti Hasanah, Email: sitihasanah@unida.ac.id
}

(Diterima: 25-02-2016; Ditelaah: 25-02-2016; Disetujui: 30-03-2016)

\begin{abstract}
This study started from the premise that students 'learning habits affect the students' motivation. It is strengthened by seeing, reading and watching the existing reality in these days that students always given extra lessons beyond the limit when it will face a final exam. The purpose of this study was to test the students' learning habits on motivation to learn. Good study habits influence on motivation to learn at SDN Cisarua 03. The method used in this study is a simple linear regression. The data obtained in this study originated from the observation, documentation and questionnaire. The population in this research is class $5 \mathrm{~A}$ and $5 \mathrm{~B}$ amounting to 73 peoples, then of the 73 sampled by the number of 62 peoples. Sampling techniques in this study using random sampling with using Yamane formula taro. Instrument in this study consisted of 40 items of 20 questions for the variable study habits of student and 20 questions for the variable of learning motivation. Results from this study indicate that students' learning habits have influence with an average value of $38.20 \%$ through the regression equation $\hat{Y}=20.46+0,67 \mathrm{X}$ the remaining $61.80 \%$ is determined by other factors not included in the discussion on research this.
\end{abstract}

Keywords: learning habits, learning motivation, learning concept.

\begin{abstract}
ABSTRAK
Penelitian ini berawal dari pemikiran bahwa kebiasaan belajar siswa dapat berpengaruh terhadap motivasi belajar. Hal tersebut semakin diperkuat dengan melihat, membaca dan menyaksikan realita yang ada bahwa siswa selalu diberikan pelajaran tambahan yang melampaui batas ketika akan mengahadapi ujian akhir. Tujuan penelitian ini adalah untuk menguji kebiasaan belajar terhadap motivasi belajar siswa di SDN Cisarua 03. Metode penelitian yang digunakan pada penelitian ini adalah penelitian korelasi dengan teknik analisis regresi linier sederhana. Data yang diperoleh pada penelitian ini bersumber dari observasi, dokumentasi, dan angket. Populasi pada penelitian ini adalah kelas $5 \mathrm{~A}$ dan $5 \mathrm{~B}$ yang berjumlah 73 orang, kemudian dari 73 orang tersebut diambil sampelnya dengan jumlah 62 orang. Teknik pengambilan sampel pada penelitian ini menggunakan teknik Yamane Taro. Instrumen pada penelitian menggunakan angket yang memakai model Skala Likert. Hasil dari penelitian menunjukkan bahwa kebiasaan belajar memiliki pengaruh dengan nilai rata-rata sebesar $38,20 \%$ melalui persamaan regresi $\hat{Y}=20,46+0,67 \mathrm{X}$ sisanya $61,80 \%$ ditentukan oleh faktor lain yang tidak dibahas pada penelitian ini. Ini berarti bahwa jika nilai kebiasaan belajar siswa bertambah 1, maka nilai rata-rata motivasi belajar akan bertambah 0,67.
\end{abstract}

Kata kunci: kebiasaan belajar, motivasi belajar, konsep belajar. 
Hasanah S, O Abdurakhman, dan M Ichsan. 2016. Pengaruh kebiasaan belajar terhadap motivasi belajar siswa. Didaktika Tauhidi 3(1): 44-47.

\section{PENDAHULUAN}

Pendidikan merupakan suatu aspek kehidupan yang sangat mendasar bagi pembangunan sumber daya manusia suatu Negara. Penyelenggaraan pendidikan di sekolah yang melibatkan guru sebagai pendidik dan siswa sebagai peserta didik diwujudkan dengan adanya interaksi belajar mengajar atau proses pembelajaran (Iskandar, 2012). Guru sebagai perancang pembelajaran dengan sadar merencanakan pembelajaran secara sistematis kepada siswanya sehingga proses pembelajaran akan berjalan dengan efektif.

Pembelajaran efektif merupakan pembelajaran yang bermanfaat bagi siswa maupun gurunya dan siswa sebagai objek pertama untuk guru dalam menentukan strategi pembelajaran yang tepat. Guru harus memberikan pembelajaran yang efektif kepada siswa sehingga siswa dapat termotivasi dalam mengikuti pelajaran di kelas dan tujuan pembelajaran akan tercapai. Motivasi siswa untuk belajar tidak hanya dipengaruhi oleh cara guru dalam memberikan pelajaran saja, tetapi banyak faktor yang dapat mempengaruhi motivasi belajar terutama dari kebiasaan belajar siswa yang sering dilakukan secara terus menerus. Setiap orang yang belajar akan mengalami perubahan tingkah laku, baik aspek pengetahuan, perilaku, dan keterampilan. Ketiga aspek ini akan timbul pada diri siswa jika siswa memiliki motivasi yang tinggi untuk belajar. Membiasakan anak untuk belajar merupakan hal yang paling penting. Kebiasaan belajar yang terus dibina dari waktu ke waktu akan memberikan manfaat kepada banyak pihak guru, orang tua dan anak.

Permasalahan yang terjadi di Indonesia mengenai kebiasaan siswa pada saat ini adalah kebiasaan belajar siswa yang tidak efektif seperti belajar di akhir semester, belajar ketika hanya akan ada ulangan saja, menyia-nyiakan waktu luang, dan lain sebagainya. Hal ini membuat pihak sekolah memberikan tambahan belajar di waktu yang tidak kondusif yaitu pada saat mendekati ujian nasional karena setiap sekolah mempunyai ambisi untuk menjadi sekolah terbaik dengan lulusan di atas ratarata. Kebiasaan belajar yang efektif akan ditanamkan pada siswa dari sejak duduk di kelas 1, sehingga ketika siswa berada di kelas akhir tidak perlu dipaksa lagi untuk belajar dalam mempersiapkan ujian nasional. Ada seorang anak yang memilki IQ (Intelligence Quotient) tinggi, namun dia selalu menyepelekan belajar sehingga dia tidak mendapatkan hasil belajar yang baik dan ada anak yang memiliki IQ (Intelligence Quotient) sedang tetapi dia melakukan kebiasaan belajar yang positif dan terus menerus dilakukannya sehingga dia memiliki hasil belajar yang baik.

Lingkungan yang kondusif sangat mempengaruhi kebiasaan anak untuk melakukan hal-hal yang positif, dalam menciptakan lingkungan yang kondusif orang tua sangat berperan penting untuk mengarahkan anak. Pengarahan orang tua yang baik akan menimbulkan kebiasaan belajar yang baik juga pada diri anak. Namun, yang sering terjadi pada saat ini bahwa orang tua dalam mendidik anaknya sering kali melakukan kekerasan yang akan menjadikan jiwa anak tersebut terganggu sehingga berdampak pada perkembangannya.

\section{MATERI DAN METODE}

Penelitian ini mengguanakan metode kuantitatif dengan pendekatan hubungan kausal. Sedangkan materi yang digunakan peneliti disesuaikan dengan indikatorindikator dari setiap variable penelitian. Adapun indicator dari motivasi belajar adalah sebagai berikut: a). Adanya hasrat dan keinginan berhasil; b). Adanya dorongan dan kebutuhan dalam belajar; c) Adanya harapan dan cita-cita masa depan; 
d). Adanya penghargaan dalam belajar; e) Adanya kegiatan belajar yang menarik; f). Adanya lingkungan yang kondusif (Hamzah, 2013:23).

Sementara indikator untuk variabel kebiasaan belajar adalah sebagai berikut: a). Mengatur jadwal belajar; b). Cara belajar kelompok; c). Cara mengikuti pelajaran; d). cara mengambil keputusan. (Djaali, 2007: 128).

Indikator-indikator penelitian tersebut kemudian diolah untuk menjadi beberapa pernyataan yang dimasukkan kepada sebuah angket dan kemudian disebarkan kepada objek penelitian yaitu kels 5 di SDN Cisarua 03.

\section{Sumber Data}

Sumber data pada penelitian ini terdiri dari sumber data primer dan sumber data sekunder. Sumber data primer adalah sumber data yang langsung memberikan data kepada pengumpul data, sedangkan sumber data sekunder merupakan sumber yang tidak langsung memberikan data kepada pengumpul data (Sugiyono, 2010). Peneliti mendapatkan sumber data primer berupa hasil wawancara terhadap kepala sekolah dan siswa melalui angket yang telah disebarkan kepada mereka. Adapun sumber data sekunder didapatkan dari buku-buku bacaan dan internet.

\section{HASIL DAN PEMBAHASAN}

Hasil penelitian ini menunjukkan bahwa terdapat pengaruh kebiasaan belajar siswa terhadap motivasi belajar di SDN Cisarua 03. Hal tersebut diambil berdasarkan hasil dari perhitungan pada analisis regresi linier sederhana dengan persamaan regresi $\hat{Y}=$ $20,46+0,67 X$. Persamaan regresi tersebut dapat diartikan bahwa jika nilai kebiasaan siswa bertambah 1, maka nilai rata-rata motivasi belajar akan bertambah 0,67. Kebiasaan belajar yang dimaksud adalah semakin baik kebiasaan belajar siswa, maka ketika siswa merasa bahwa dirinya membutuhkan motivasi akan terlihat dari kebiasaannya untuk merealisasikan motivasi tersebut.

Kebiasaan belajar siswa akan berpengaruh terhadap motivasi belajar karena ketika siswa merasa bahwa dirinya membutuhkan motivasi maka dapat dilihat dari kebiasaannya untuk merealisasikan motivasi tersebut. Dengan kebiasaan siswa yang baik, maka motivasi itu akan muncul pada diri siswa dengan sendirinya. Hal ini sesuai dengan teori $X$ dan $Y$ yang dikembangkan oleh McGregor. McGregor beranggapan bahwa teori $\mathrm{X}$ menganggap sebagian manusia lebih suka diperintah dan tidak tertarik dengan rasa tanggungjawab, serta masih bersifat anak-anak (Makmun, 2014). Orang-orang yang tergolong teori $X$ pada hakikatnya tidak suka bekerja, berkemampuan kecil untuk mengatasi masalah-masalah organisasi dan hanya membutuhkan motivasi fisiologis saja. Oleh karena itu, perlu diawasi secara ketat.

\section{KESIMPULAN DAN IMPLIKASI}

Berdasarkan penelitian ini dapat ditarik kesimpulan sebagai berikut: 1) uji hipotesis pada penelitian ini diperoleh $r=0,6181>r$ tabel $=0,254$ sehingga memiliki hubungan yang signifikan, sedangkan koefisien determinasinya $r^{2}=0,6181=0,3820$. Hal ini berarti bahwa nilai rata-rata motivasi belajar $38,20 \%$ ditentukan oleh nilai kebiasaan belajar siswa melalui persamaan regresi $\hat{Y}=20,46+0,67 \mathrm{X}$. Sisanya $61,80 \%$ ditentukan oleh faktor lain; 2) berdasarkan analisis data diperoleh persamaan regresi yaitu $\hat{Y}=20,46+0,67 \mathrm{X}$. Hal ini berarti bahwa jika nilai kebiasaan belajar siswa bertambah 1 , maka nilai rata-rata motivasi belajar akan bertambah 0,67. Setelah diuji linieritas regresinya dengan dua tahap yaitu uji keberartian dan uji linieritas; 3 uji keberartian pada penelitian ini diperoleh koefisien $\mathrm{F}$ hitung $=37,50$ lebih besar dari pada $\mathrm{F}$ tabel $=4,00$ dengan taraf kesalahan 5\%. Ini berarti bahwa Ha diterima dan Ho ditolak dengan kesimpulan data tersebut berarti $(b \neq 0)$. Adapun uji linieritasnya diperoleh Fhitung $=0,17$ lebih kecil dari 
pada Ftabel $=$ 2,07 dengan taraf kesalahan 5 $\%$. Ini berarti bahwa $\mathrm{Ha}$ ditolak dan $\mathrm{Ho}$ diterima dengan kata lain bahwa data tersebut regresi linier, 4) semakin baik kebiasaan belajar siswa, maka akan semakin tinggi motivasi yang dimilikinya.

\section{DAFTAR PUSTAKA}

Djaali H. 2007. Psikologi pendidikan. Edisi Pertama. Buah Aksara, Jakarta.
Hamzah B Uno. 2013. Teori motivasi dan pengukurannya. Edisi pertama. Bumi Aksara, Jakarta.

Iskandar. 2012. Psikologi pendidikan. Edisi Pertama. Referensi, Jakarta.

Khairani M. 2014. Psikologi belajar. Aswaja Pressindo, Yogyakarta.

Sugiyono. 2010. Metode penelitian. Edisi Pertama. Alfabeta, bandung. 